\title{
KEJAHATAN PERTAMBANGAN DALAM PERSPEKTIF KEADILAN BERMARTABAT
}

\author{
Teguh Prasetyo \\ Fakultas Hukum Universitas Kristen Satya Wacana Salatiga \\ e-mail: prof.teguh.prasetyo@gmail.com
}

\begin{abstract}
ABSTRAK
Hukum selalu hadir untuk mengatasi kejahatan dan menghadirkan kembali keadilan. Urgensi kehadiran hukum mengatasi kejahatan atau ketidakadilan pertambangan terlihat dalam rumusan UUD 1945 Pasal 33 ayat (3). Bahwa bumi, air, dan kekayaan alam yang terkandung didalamnya dikuasai oleh negara dan dipergunakan untuk sebesar-besar kemakmuran rakyat. Keadilan Bermartabat memotret, menggambarkan dan terutama menjelaskan bagaimana eksistensi hukum mengatasi kejahatan maupun pelanggaran atau ketidakadilan yang selalu mengancam eksistensi dunia pertambangan. Suatu contoh dari gambaran Keadilan Bermartabat tentang kejahatan dan kehadiran hukum untuk mencegah dan mengatasi kejahatan dalam bidang pertambangan dalam sistem hukum Pancasila itu antara lain dapat terlihat manifestasinya dalam rumusan ketentuan dalam UU No. 4 Tahun 2009 tentang Pertambangan Mineral dan Batubara. Gambaran Keadilan Bermartabat tentang kejahatan atau ketidakadilan serta upaya untuk mengatasi kejahatan dan ketidakadilan pertambangan antara lain dapat ditemukan dalam rumusan pasal-pasal mulai Pasal 158 sampai dengan Pasal 165 UU No. 4 Tahun 2009 tentang Pertambangan Mineral dan Batubara.
\end{abstract}

Kata Kunci: pertambangan, Teori Keadilan Bermartabat.

\section{ABSTRACT}

The law has always been around to overcome evil and restore justice. The urgency of the ever presence of law in handling mining crime activities could be seen in the 1945 Constitution of the Republic of Indonesia, Article 33 Section 3. It is stipulated that land, water and wealth of it's natural resources are in the possession of the State and used for the utmost welfare of the people. The Dignified Justice has potrayed, described and particularly explained how the law exists to overcome crimes and offences or injustices which always threaten the mining industries. Among other things, one of the examples ofthe Dignified Justice Theory describes how the law plays it's role to prevent and solve crimes in the Pancasila Legal System which is in the Law number 4/2009 on Minerals and Coals Mining. The details on the types of crimes and offences on the mining field and all the legal efforts to overcome those injustices might be found in the Articles of 158 to 165 of the Law number 4/2009 on Minerals and Coals Mining. Keywords: mining, Dignified Justice Theory.

\section{PENDAHULUAN}

Dunia pertambangan sama dengan semua dunia aktivitas manusia dan organisasi manusia, di dalam suatu masyarakat manusia tertentu dan di hampir semua masyarakat negara di dunia bukanlah aktivitas yang bebas dari kejahatan atau ketidakadilan yang mengancam eksistensinya. Hukum pun hadir untuk mengatasi kejahatan dan menghadirkan kembali keadilan tersebut. Urgensi kehadiran hukum mengatasi kejahatan atau ketidakadilan pertambangan tersebut terlihat dalam rumusan penegasan dalam
Undang-Undang Dasar 1945 Pasal 33 ayat (3) yang menegaskan bahwa bumi, air, dan kekayaan alam yang terkandung di dalamnya dikuasai oleh negara dan dipergunakan untuk sebesar-besar kemakmuran rakyat.

Penegasan itu kembali diperinci dalam UndangUndang Republik Indonesia Nomor 4 Tahun 2009 tentang Pertambangan Mineral dan Batubara (yang selanjutnya disebut UU Minerba). Bahwa mengingat mineral dan batubara sebagai kekayaan alam yang 
terkandung di dalam bumi itu merupakan sumber daya alam yang tak terbarukan, pengelolaannya perlu dilakukan seoptimal mungkin, efisien, transparan, berkelanjutan dan berwawasan lingkungan, serta berkeadilan agar memperoleh manfaat sebesar-besar bagi kemakmuran rakyat secara berkelanjutan.

Terlihat dalam judul di atas, jika tulisan ini disusun dalam perspektif Teori Keadilan Bermartabat atau, dapat disingkat dengan Keadilan Bermartabat atau Dignified Justice Theory ${ }^{1}$ saja. Perspektif Keadilan Bermartabat memotret, menggambarkan dan terutama menjelaskan bagaimana eksistensi hukum mengatasi kejahatan maupun pelanggaran atau ketidakadilan yang selalu mengancam eksistensi dunia pertambangan. Suatu contoh dari gambaran Keadilan Bermartabat tentang kejahatan dan kehadiran hukum untuk mencegah dan mengatasi kejahatan dalam bidang pertambangan dalam sistem hukum Pancasila itu antara lain dapat terlihat manifestasinya dalam rumusan ketentuan dalam UU Minerba.

Keadilan Bermartabat itu bukan suatu jenis konsep keadilan seperti yang sudah sangat umum dipahami selama ini, maka ada baiknya deskripsi singkat mengenai Keadilan Bermartabat itu saya gambarkan secara singkat sebagai berikut. Keadilan Bermartabat adalah suatu Grand Teori Hukum. Sebagai Teori Hukum yang baru, Keadilan Bermartabat berfungsi untuk menjelaskan dan memberi justifikasi suatu sistem hukum yang berlaku, yang berbeda dengan teori-teori barat yang selama ini dirujuk. Teori Keadilan Bermartabat menjelaskan dan memberi justifikasi suatu sistem hukum dengan antara lain suatu postulat ${ }^{2}$ bahwa hukum itu ada, dan tumbuh dalam jiwa bangsa atau Volksgeist.

Teori Keadilan Bermartabat tidak anti terhadap teori-teori yang selama ini ada dan dirujuk dalam menjelaskan hukum yang berlaku di Indonesia. Namun Keadilan Bermartabat berusaha memberi teladan untuk ber-hukum, termasuk mencari, dan membangun atau melakukan konstruksi maupun rekonstruksi atas hukum serta penjelasan tentang

\footnotetext{
${ }^{1}$ Penjelasan yang cukup mendalam mengenai teori ini dapat dilihat dalam: Teguh Prasetyo, Keadilan Bermartabat Perspektif Teori Hukum, Cetakan Pertama, Nusa Media, Bandung, 2015.

2 Dimaksudkan dengan postulat, yaitu pernyataan tentang kebenaran yang "sudah pasti jelas dengan sendirinya dan oleh sebab itu tak akan terbantahkan". Hal itu terdapat dalam Soetandyo Wignjosoebroto, Pergeseran Paradigma dalam Kajian-kajian Sosial dan Hukum, Edisi Revisi, Cetakan Pertama, Setara Press, Malang, 2013, fn. 14, h. 46.
}

hukum itu dari falsafah atau filosofis yang digali dari dalam bumi Indonesia sendiri; tidak harus bergantung kepada teori-teori, konsep-konsep yang dikembangkan di dalam sistem hukum yang lain. Konsep keadilan misalnya yang selama ini dimengerti adalah konsepsi keadilan Plato dan Aristoteles yang berasal dari jaman yang berbeda dan tempat yang berbeda, yaitu Yunani Kuno. Sudah saatnya kita mempunyai konsepsi tentang keadilan yang dibangun dari jiwa bangsa sendiri, yaitu Pancasila.

Dalam sistem hukum Pancasila maka Pancasila adalah jiwa bangsa atau Volkgeist Indonesia. Pancasila sebagai jiwa bangsa terdiri dari lima sila, terutama sila Ketuhanan Yang Maha Esa, Kemanusiaan yang adil dan beradab, begitu pula sila Keadilan sosial bagi seluruh rakyat Indonesia menjadi sumber dari segala sumber hukum, atau menjadi Kesepakatan Pertama. ${ }^{3}$ Dalam hal ini, postulat lainnya yang tidak kalah penting dalam Keadilan Bermartabat adalah bahwa hukum itu harus dilihat sebagai suatu sistem.

Mengacu kepada perspektif sistem, maka peraturan perundang-undangan yang berlaku di dalam suatu sistem hukum Pancasila tidak dapat dilepaskan dari Pancasila sebagai Kesepakatan Pertama. Substansi dari setiap peraturan perundangundangan yang berlaku mau atau tidak mau harus sejalan atau sejiwa dengan Pancasila sebagai jiwa bangsa. Oleh sebab itu, Pasal 33 UUD 1945 adalah perwujudan atau manifestasi lebih lanjut dari Pancasila sebagai jiwa bangsa. Begitu pula seterusnya rumusan pasal-pasal dalam UU Minerba, berbagai peraturan perundang-undangan yang melaksanakan undang-undang tersebut serta tindakan konkret pejabat administrasi negara yang ada di lapangan dalam bidang pertambangan, semuanya harus pula dilihat sebagai manifestasi yang paling konkret dari Pancasila sebagai Kesepakatan Pertama atau dapat dikatakan merupakan jiwa bangsa yang saat ini hidup, atau berlaku dan harus menjadi pedoman, khususnya dalam kegiatan pertambangan.

Gambaran Keadilan Bermartabat tentang kejahatan atau ketidakadilan serta upaya untuk mengatasi kejahatan dan ketidakadilan pertambangan dalam tulisan ini dikhususkan pada pasal-pasal mulai Pasal 158 sampai dengan Pasal 165 UU Minerba.

${ }^{3}$ Teguh Prasetyo dan Abdul Halim Barkatullah, Filsafat, Teori, \& Ilmu Hukum Pemikiran menuju Masyarakat yang Berkeadilan dan Bermartabat, Cetakan ke-1, RajaGrafindo Persada, Jakarta, 2012, h. 367. 
Gambaran atas rumusan-pasal pasal di atas diharapkan dapat dijumpai hakikat, berikut jenis-jenis kejahatan pertambangan, yaitu perbuatan dalam bidang pertambangan yang dilarang dan diancam dengan pidana oleh ketentuan hukum pidana. Kejahatan pertambangan adalah perbuatan pidana, atau bentuk ketidakadilan yang mungkin dilakukan oleh subyek pelaku tindak pidana pertambangan, ${ }^{4}$ yang dapat dikemukakan sebagai berikut di bawah ini.

Kejahatan pertambangan yang pertama, yaitu melakukan usaha penambangan tanpa Izin Usaha Pertambangan (IUP); Izin Pertambangan Rakyat (IPR) dan Izin Usaha Pertambangan Khusus (IUPK). Kedua, menyampaikan laporan yang tidak benar atau misrepresentation atau keterangan palsu atau fraud. Kejahatan yang ketiga, yaitu melakukan eksporasi tanpa memiliki IUP atau IUPK. Kejahatan pertambangan yang keempat, yaitu mempunyai IUP Eksporasi tetapi melakukan kegiatan operasi produksi. Kejahatan kelima, menampung, memanfaatkan, melakukan pengolahan dan pemurnian, pengangkutan, penjualan mineral dan batubara yang bukan pemegang IUP, IUPK, atau izin. Keenam, merintangi atau menganggu kegiatan usaha pertambangan. Ketujuh, yaitu kejahatan yang berhubungan dengan penggunaan kekuasaan negara dalam pengaturan, kontrol dan pengawasan atas kegiatan usaha pertambangan dalam bentuk pemberian izin. Utamanya, izin seperti IUP, IPR, atau IUPK. Kejahatan karena Pemberian izin itu bertentangan dan menyalahgunakan kewenangannya. Semua jenis kejahatan atau bentuk ketidakadilan dalam bidang pertambangan itu sudah ditentukan terlebih dahulu dalam legislasi. Antara lain, dalam UU Minerba.

Sementara jenis sanksi yang dapat dijatuhkan terhadap pelaku kejahatan pertambangan sebagaimana dikemukakan di atas juga diatur dalam UU Minerba. Ada tiga jenis sanksi pidana yang dijatuhkan kepada pelaku orang perseorangan yang melakukan kejahatan pertambangan. Ketiga jenis sanksi itu, yaitu pidana penjara; pidana denda; dan pidana tambahan.

Masih juga dalam perspektif keadilan bermartabat, tidak sekedar ancaman berupa sanksi pidana, yang dapat dijumpai dalam rumusan ketentuan atau

${ }^{4}$ Dalam Pasal 38 UU Minerba, dapat diketahui bahwa subyek hukum pertambangan, antara lain, yaitu: a. badan usaha. Badan usaha dalam ketentuan ini meliputi juga badan usaha milik negara dan badan usaha milik daerah; b. koperasi; dan c. perseorangan. pasal-pasal dalam peraturan perundang-undangan. Peraturan perundang-undangan yang berlaku di dalam suatu negara, juga ada begitu banyak putusan pengadilan yang tersebar dan dapat disimak dalam situs Mahkamah Agung Republik Indonesia yang saat ini dapat diakses dengan mudah; adalah manifestasi paling konkret dari jiwa bangsa atau Volksgeist. Jiwa bangsa atau Volksgeist Indonesia yaitu Pancasila.

Tujuan tulisan ini adalah untuk memahami manifestasi dari pemikiran-pemikiran mengenai hakikat kejahatan pertambangan dan usaha untuk mengatasi kejahatan atau ketidakadilan pertambangan itu menurut Volksgeist Indonesia dapat dilihat secara konkrit dan dapat dijelaskan dengan baik dengan memperhatikan rumusan ketentuan dalam peraturan perundang-undangan yang mengatur mengenai pertambangan. Oleh karena itu dengan menggunakan pendekatan perundang-undangan, maka isu hukum dalam tulisan ini adalah bagaimanakah manifestasi Teori Keadilan Bermartabat pada UU Minerba?

\section{PEMBAHASAN \\ Jenis dan Skopa Kejahatan dan Pelanggaran Pertambangan}

Dalam Pasal 158 UU Minerba dijumpai jenis-jenis kejahatan pertambangan. Berikut di bawah ini uraian lebih jauh tentang jenis kejahatan pertambangan sebagaimana dimaksud dalam UU Minerba.

Keberadaan UU Minerba tidak lepas dari tuntutan hukum. Menurut Pasal 1 ayat (1) Kitab UndangUndang Hukum Pidana (KUHP), sesuatu perbuatan boleh dihukum, atas kekuatan aturan hukuman dalam undang-undang yang diadakan lebih dahulu daripada perbuatan itu. Apabila terlebih dahulu tidak diadakan peraturan perundang-undangan yang memuat hukuman yang dapat dijatuhi atas penjahat atau pelanggar, maka perbuatan yang bersangkutan bukan perbuatan yang dikenai hukuman (nullum delictum, nulla poena sine praevia lege poenali).

Namun, sebelum perincian lebih lanjut mengenai jenis-jenis kejahatan pertambangan tersebut, ada baiknya terlebih dahulu dikemukakan di sini bahwa konsep kejahatan merupakan konsep yang sudah dikenal dalam KUHP, diatur dalam Buku Kedua KUHP. Konsep Kejahatan dalam KUHP dibedakan dengan konsep pelanggaran, yang diatur dalam Buku III. Tujuan kategorisasi kejahatan dan pelanggaran menurut KUHP itu dimaksudkan untuk membawa kepastian karena ada keragu-raguan batas antara 
kejahatan dan pelanggaran. Pelaku kejahatan disebut penjahat, pelaku pelangggaran disebut pelanggar. $^{5}$ Sangat disayangkan, baik itu pengertian dari konsep tentang kejahatan maupun pengertian dari konsep tentang pelanggaran tidak dapat dijumpai penjelasannya di dalam KUHP. Pengertian tentang kejahatan kemudian diserahkan kepada ilmu pengetahuan untuk memberikan dasarnya, tetapi tampaknya tidak ada yang sepenuhnya memuaskan, ${ }^{6}$ namun hukum tidak frustrasi. Hukum adalah sumber kebahagiaan.

Untuk sementara, telah dicoba dibedakan bahwa kejahatan merupakan rechtsdelict atau delik hukum dan pelanggaran merupakan wetsdelict atau delik undang-undang. Delik hukum adalah pelanggaran hukum yang dirasakan melanggar rasa keadilan, misalnya perbuatan seperti pembunuhan, melukai orang lain, mencuri, dan sebagainya. Sedangkan delik undang-undang, misalnya saja keharusan untuk mempunyai SIM bagi yang mengendarai kendaraan bermotor di jalan umum, atau tidak mengenakan helm ketika mengendarai sepeda motor. Ada pandangan yang hampir sudah menjadi sesuatu yang terpaksa harus diikuti, bahwa dalam delik undang-undang itu tidak tersangkut sama sekali masalah keadilan. ${ }^{7}$

Menurut pandangan saya, apabila diikuti dikte hukum atau the dictate of the law bahwa undangundang itu hakikatnya adalah suatu wujud atau manifestation rumusan konkret tentang cita hukum atau rasa keadilan dan justice yang terdapat dalam suatu jiwa bangsa atau Volksgeist, maka besar sekali kemungkinan simplifikasi pembedaan kejahatan dan pelanggaran sebagaimana dikemukakan di atas menjadi kabur dan hampir kehilangan makna. UU Minerba juga tidak menentukan secara tegas garis demarkasi kejahatan dan pelanggaran, apalagi perlakuan tidak adil.

Hanya saja dalam kenyataannya apabila penelitian yang lebih cermat dilakukan terhadap substansi UU Minerba ternyata, undang-undang itu tidak dapat dilepaskan dengan keadilan. Konsiderans undang-undang itu, misalnya, menunjuk kepada cara pengelolaan mineral dan batu bara dan cara

${ }^{5}$ E. Utrecht/Moh. Saleh Djindang, Pengantar dalam Hukum Indonesia, Cetakan Kesepuluh, Ichtiar Baru dan Sinar Harapan, Jakarta, 1983, h. 388.

${ }^{6}$ Teguh Prasetyo, Hukum Pidana, Edisi Revisi, Cetakan Keempat, RajaGrafindo Persada, Jakarta, 2013, h. 58.

${ }^{7}$ Ibid. pendistribusian hasilnya bagi hajat hidup orang banyak, yaitu seluruh tumpah darah Indonesia oleh Negara, harus berkeadilan. Keadilan, dengan demikian antara lain adalah cara pengelolaan dan distribusi hasil-hasil pertambangan yang sebesarbesarnya bagi kesejahteraan negara dan bangsa atau Rakyat Indonesia.

Perhatikan keadilan sebagai suatu epistimologi yang terdapat dalam rumusan "menimbang", UU Minerba menegaskan bahwa mineral dan batubara yang terkandung dalam wilayah hukum pertambangan Indonesia merupakan kekayaan alam tak terbarukan sebagai karunia Tuhan Yang Maha Esa yang mempunyai peranan penting dalam memenuhi hajat hidup orang banyak, karena itu pengelolaannya harus dikuasai oleh negara untuk memberi nilai tambah secara nyata bagi perekonomian nasional dalam usaha mencapai kemakmuran dan kesejahteraan rakyat secara berkeadilan.

Selain sebagai bintang pemandu dalam cara pengelolaan seperti dirumuskan pembuat UU Minerba, dalam undang-undang itu juga dapat dijumpai asas keadilan. Asas keadilan merupakan asas dalam pengelolaan dan pemanfaatan mineral dan batubara dimana di dalam pemanfaatan itu harus memberikan hak yang sama rasa dan rata bagi masyarakat banyak. Masyarakat dapat diberikan hak untuk mengelola dan memanfaatkan mineral dan batubara, dan juga dibebani kewajiban untuk menjaga kelestarian lingkungan hidup.

Keadilan merupakan tujuan yang paling terpenting dan utama dalam hukum. Membicarakan masalah keadilan sama dengan membicarakan mengenai hukum itu sendiri. Meskipun sulit dirumuskan, pembahasan mengenai keadilan selalu menjadi bahan pembicaraan pada setiap aliran filsafat hukum. Keadilan dapat dibedakan menjadi tiga jenis. ${ }^{8}$

Pertama, yaitu keadilan umum atau justitia generalis atau keadilan legal, yaitu keadilan menurut kehendak undang-undang yang harus ditunaikan demi kepentingan umum. Keadilan jenis ini secara

\footnotetext{
${ }^{8}$ Adalah penting untuk diperhatikan agar tidak terjadi kesalahpahaman, bahwa jenis-jenis keadilan sebagaimana dikemukakan di atas hanyalah berkaitan dengan konsep tentang keadilan. Berbeda dengan Teori Keadilan Bermartabat. Keadilan Bermartabat atau Teori Keadilan bermartabat bukan satu jenis keadilan seperti dikemukakan di atas, demikian pula bukan jenis keadilan yang hanya berlaku dalam sistem peradilan pidana anak, yaitu keadilan restoratif atau restorative justice. Keadilan Bermartabat adalah suatu Grand Theory Hukum.
} 
eksplisit dipergunakan pembuat UU Minerba, yang digambarkan dalam artikel ini.

Kedua, keadilan khusus, yaitu keadilan atas dasar kesamaan atau proporsionalitas. Jenis keadilan dalam kategori konsep yang kedua ini secara tersirat banyak dijumpai dalam UU Minerba. Kategori jenis keadilan yang kedua tersebut dibedakan menjadi tiga jenis, yaitu: keadilan distributif atau justitia distributiva atau keadilan yang secara proporsional diterapkan dalam lapangan hukum publik. Keadilan komutatif atau justitia commutativa, yaitu keadilan dengan mempersamakan antara prestasi dan kontraprestasi. Keadilan vindikatif atau justitia vindikativa, yaitu keadilan dalam hal menjatuhkan hukuman atau ganti kerugian dalam tindak pidana. ${ }^{9}$

Sebagaimana sudah umum diketahui, asas hukum atau prinsip hukum merupakan pikiran dasar yang umum sifatnya atau merupakan latar belakang dari peraturan yang konkret yang terdapat dalam dan di belakang setiap sistem hukum yang terjelma dalam peraturan perundang-undangan dan putusan hakim yang merupakan hukum positif dan dapat diketemukan dalam peraturan konkret tersebut. Fungsi ilmu hukum adalah mencari asas hukum itu dalam hukum positif, ${ }^{10}$ atau dalam hukum yang digali dari "dalam bumi sendiri". Asas hukum itu, dalam hal ini keadilan sebagai asas hukum, merupakan hidup kejiwaan kita atau Volksgeist. ${ }^{11}$ Dalam perspektif Teori Keadilan Bermartabat, atau Keadilan Bermartabat, keadilan itu adalah tempat berhimpunnya tiga tujuan hukum yang dikemukakan oleh Gustav Radbruch; ${ }^{12}$ keadilan, kepastian dan kemanfaatan. ${ }^{13}$

Atas dasar itu, jalan prinsipil dapat dipilih untuk mengkonseptualisasikan perbuatan pidana yang diatur dalam UU Minerba sebagai jenis-jenis kejahatan saja, atau mungkin pelanggaran saja. Dalam tulisan

\footnotetext{
${ }^{9}$ Teguh Prasetyo, Hukum dan Sistem Hukum Berdasarkan Pancasila, Cetakan Pertama, Media Perkasa, Yogyakarta, 2013, h. 10.

${ }^{10}$ Sudikno Mertokusumo, Mengenal Hukum Suatu Pengantar, Cetakan Kedua, Liberty, Yogyakarta, 1999, h. 35-35.

${ }^{11}$ Ibid., h. 35.

${ }^{12}$ Uraian yang mengantinomikan tujuan-tujuan hukum yaitu: keadilan, kemanfaatan dan kepastian hukum (Justice, Expediency, Legal Certainty), dapat dilihat dalam Kurt Wilk, $20^{\text {th }}$ Century Legal Philosophy Series, Vol. IV, The Legal Philosophies of Lask, Radbruch, and Dabin, Harvard University Press, 1950, h. 107.

${ }^{13}$ Tri Tunggal Hukum, dalam Teguh Prasetyo, Keadilan Bermartabat Perspektif Teori Hukum, Cetakan Pertama, Nusa Media, Bandung, 2015, h. 112-113.
}

ini, perbuatan-perbuatan yang dilarang dalam UU Minerba dan diancam dengan sanksi pidana tersebut adalah sama dengan bentuk-bentuk atau jenis-jenis kejahatan pertambangan atau ketidakadilan dalam dunia pertambangan. Dengan perkataan lain, semua perbuatan yang bertentangan dengan UU Minerba adalah perbuatan-perbuatan jahat atau perbuatanperbuatan yang menimbulkan ketidakadilan. Pihak negara, sebagai pihak prinsipal bertanggungjawab untuk memulihkan pengelolaan pertambangan secara berkeadilan.

Adapun skopa kejahatan pertambangan atau ketidakadilan dalam pengelolaan pertambangan, yaitu jenis kejahatan pertama menurut UU Minerba merupakan kejahatan atau ketidakadilan yang terjadi dalam sebagian atau seluruh tahapan kegiatan pertambangan. Tahapan-tahapan tersebut meliputi tahapan penelitian, tahapan pengelolaan dan tahapan pengusahaan mineral ${ }^{14}$ atau batubara. ${ }^{15}$

Secara lebih terperinci, dalam UU Minerba dikemukakan sejumlah kegiatan dalam pentahapan tersebut. Pentahapan dimaksud meliputi: pentahapan penyelidikan umum, pentahapan eksplorasi, pentahapan studi kelayakan, pentahapan konstruksi, pentahapan penambangan, pentahapan pengolahan dan pemurnian, pentahapan pengangkutan dan penjualan, serta pentahapan kegiatan pasca tambang.

Semua skopa kejahatan pertambangan yang dapat terjadi dalam berbagai pentahapan kegiatan pertambangan sebagaimana sudah saya kemukakan di atas tersebut di dalamnya dapat berlangsung jenis kejahatan atau bentuk ketidakadilan dalam kategorinya yang pertama. Kejahatan itu dapat dilakukan oleh perorangan maupun badan hukum yang semuanya dapat disebut sebagai korporasi. Terhadap korporasi yang termasuk badan hukum, sanksi pidana diatur tersendiri.

Pasal 163 ayat (1) UU Minerba mengandung perumusan: Dalam hal tindak pidana sebagaimana dimaksud dalam bab ini dilakukan oleh suatu badan hukum, selain pidana penjara dan denda terhadap pengurusnya, pidana yang dapat dijatuhkan terhadap badan hukum tersebut berupa pidana denda dengan pemberatan ditambah 1/3 (satu per tiga) kali dari

\footnotetext{
${ }^{14}$ Mineral adalah senyawa anorganik yang terbentuk di alam, yang memiliki sifat fisik dan kimia tertentu serta susunan kristal teratur atau gabungannya yang membentuk batuan, baik dalam bentuk lepas atau padu.

${ }^{15}$ Batubara adalah endapan senyawa organik karbonan yang terbentuk secara alamiah dari sisa tumbuh-tumbuhan.
} 
ketentuan maksimum pidana denda yang dijatuhkan. Selanjutnya, dalam Pasal 163 ayat (2) diatur: Selain pidana denda sebagaimana dimaksud pada ayat (1) badan hukum dapat dijatuhi pidana tambahan berupa: pencabutan izin usaha; dan/atau pencabutan status badan hukum. Selanjutnya, bagi korporasi dalam kategori perseorangan dalam Pasal 164 dirumuskan, bahwa selain ketentuan sebagaimana dimaksud dalam Pasal 158, Pasal 159, Pasal 160, Pasal 161, dan Pasal 162 kepada pelaku tindak pidana dapat dikenai pidana tambahan berupa: perampasan barang yang digunakan dalam melakukan tindak pidana; perampasan keuntungan yang diperoleh dari tindak pidana; dan/atau kewajiban membayar biaya yang timbul akibat tindak pidana.

Persyaratan bahwa tindakan-tindakan dalam pentahapan pertambangan itu menjadi jenis kejahatan atau bentuk ketidakadilan yang pertama apabila di dalam semua kegiatan di atas, memenuhi rumusan ketentuan dalam Pasal 158 UU Minerba. Yaitu, kejahatan atau bentuk ketidakadilan berupa perbuatan melakukan usaha pertambangan tanpa IUP, ${ }^{16} \mathrm{IPR},{ }^{17}$ atau IUPK. ${ }^{18}$ Bagi pelaku tindak pidana atau subyek hukum pidana pertambangan yang melakukan usaha penambangan tanpa IUP, IPR atau IUPK dipidana dengan pidana penjara paling lama sepuluh tahun dan denda paling banyak sepuluh miliar rupiah.

Pasal 37 UU Minerba mengandung pengaturan tentang pihak-pihak yang mempunyai wenang untuk menerbitkan IUP. Adapun pihak-pihak yang berwenang untuk menerbitkan IUP tersebut dapat dikemukakan sebagai berikut. Pihak yang pertama, yaitu Bupati atau Walikota apabila WIUP berada di dalam satu wilayah Kabupaten/Kota. Pihak selanjutnya, yaitu Gubernur apabila WIUP berada pada lintas wilayah Kabupaten/Kota dalam satu Propinsi. IUP yang diterbitkan pihak Gubernur tersebut baru diberikan apabila Gubernur telah mendapatkan rekomendasi dari Bupati/Walikota setempat sesuai dengan ketentuan peraturan perundang-undangan. Pihak lainnya yang berwenang menerbitkan IUP,

${ }^{16}$ Izin Usaha Pertambangan (IUP) adalah izin untuk melaksanakan usaha pertambangan. Hal itu diatur dalam Pasal 1 Angka (7) UU Minerba.

${ }^{17}$ Izin Pertambangan Rakyat (IPR) adalah izin untuk melaksanakan usaha pertambangan dalam wilayah pertambangan rakyat dengan luas wilayah dan investasi terbatas.

${ }^{18}$ Izin Usaha Pertambangan Khusus (IUPK) adalah izin untuk melaksanakan usaha pertambangan di wilayah izin usaha pertambangan khusus. yaitu Menteri yang menyelenggarakan urusan pemerintahan di bidang pertambangan mineral dan batubara. ${ }^{19}$

Pihak yang disebutkan terakhir ini memperoleh wewenang apabila WIUP berada pada lintas wilayah propinsi. Menteri Energi Sumber Daya Mineral (ESDM) baru dapat menerbitkan IUP apabila dia telah mendapatkan rekomendasi dari Gubernur dan Bupati/Walikota setempat sesuai dengan ketentuan peraturan perundang-undangan. Apabila pihakpihak yang berwenang sebagaimana dikemukakan di atas mengeluarkan IUP, IPR, IUPK bertindak atau melakukan sesuatu, maupun tidak melakukan sesuatu yang bertentangan dengan UU Minerba maka pihakpihak itu diberi sanksi pidana.

Jenis sanksi pidana yang dapat dikenakan terhadap pihak-pihak yang demikian itu, sekalipun mereka adalah pihak yang memiliki kewenangan publik, namun menyalahgunakan kewenangannya itu, yaitu pidana penjara dan denda. Pidana penjara paling lama sepuluh tahun dan pidana dendanya paling banyak sepuluh miliar rupiah. Penggunaan kata dan dalam rumusan ketentuan yang mengatur mengenai sanksi pidana dimaksud mengandung pengertian bahwa sifat dari pidana yang dijatuhkan adalah kumulatif.

Secara konseptual perlu ditambahkan di sini bahwa dalam hukum pidana, terminologi yang dipergunakan untuk kejahatan yang dilakukan ketiga pihak yang berwenang sebagaimana dikemukakan di atas, yaitu penyalahgunaan wewenang publik atau abus de droit, dan juga sering disebut dengan abuse of power. Sedangkan dalam UU Minerba, terminologi yang dipergunakan adalah penyalahgunaan wewenang. ${ }^{20}$

Kejahatan atau ketidakadilan dalam bidang pertambangan yang masih termasuk dalam golongan kejahatan atau ketidakadilan yang pertama sebagiamana dikemukakan di atas, yaitu pihak pemegang IUP dalam melakukan usaha penambangan bermaksud mengusahakan mineral lain, tetapi pihak tersebut tidak memenuhi kewajiban berupa pengajuan permohonan IUP baru kepada Menteri

\footnotetext{
${ }^{19}$ Saat ini Menteri dimaksud adalah menteri yang memimpin Kementerian Energi dan Sumber Daya Mineral Republik Indonesia.

${ }^{20}$ Konsep yang dipergunakan dalam Pasal 165 UU Minerba untuk menamakan pihak-pihak yang memiliki kewenangan menerbitkan IUP sebagaimana dikemukakan di atas adalah setiap orang.
} 
ESDM, Gubernur, dan Bupati/Walikota sesuai dengan kewenangan dari ketiga pihak yang berwenang tersebut.

Dalam hal ini perlu ditambahkan di sini, bahwa IUP terdiri atas dua tahap: pertama, IUP Eksplorasi meliputi kegiatan penyelidikan umum, eksplorasi, dan studi kelayakan; kedua, IUP Operasi Produksi meliputi kegiatan konstruksi, penambangan, pengolahan dan pemurnian, serta pengangkutan dan penjualan. Pemegang IUP Eksplorasi dan pemegang IUP Operasi Produksi dapat melakukan sebagian atau seluruh kegiatan penyelidikan umum, eksplorasi, dan studi kelayakan, dan kegiatan operasi produksi seperti kegiatan konstruksi, penambangan, pengolahan dan pemurnian, serta pengangkutan dan penjualan.

IUP dimaksud dalam diberikan untuk satu jenis mineral atau batubara. Sanksi hukuman pidana yang dapat dijatuhkan kepada pihak yang melakukan kejahatan atau ketidakadilan sebagaimana dikemukakan di atas sama dengan sanksi yang dapat dijatuhkan kepada pihak yang melakukan kejahatan atau bentuk ketidakadilan pertama, yang sudah terlebih dahulu dikemukakan di atas.

Jenis kejahatan atau bentuk ketidakadilan dalam bidang pertambangan yang ketiga, yaitu setiap orang yang melakukan usaha penambangan tanpa IUP Operasi Produksi diberikan oleh: pertama, Bupati/Walikota apabila lokasi penambangan, lokasi pengolahan dan pemurnian, serta pelabuhan berada di dalam satu wilayah kabupaten kota; kedua, Gubernur apabila lokasi penambangan, lokasi pengolahan dan pemurnian, serta pelabuhan berada di dalam wilayah Kabupaten/Kota yang berbeda setelah mendapatkan rekomendasi dari Bupati/Walikota setempat sesuai dengan ketentuan peraturan perundang-undangan; dan Menteri apabila lokasi penambangan, lokasi pengolahan dan pemurnian, serta pelabuhan berada di dalam wilayah propinsi yang berbeda setelah mendapatkan rekomendasi dari Gubernur dan Bupati/ Walikota setempat sesuai dengan ketentuan peraturan perundang-undangan.

Selanjutnya, bentuk kejahatan atau ketidakadilan pertambangan berikutnya, yang masih berada dalam kategori kejahatan atau keadilan dalam bidang pertambangan seperti sudah dikemukakan di atas, yaitu Bupati/Walikota tidak memberikan IPR terutama kepada penduduk setempat, baik perseorangan maupun kelompok masyarakat dan/ atau koperasi. Begitu pula merupakan kejahatan atau bentuk ketidakadilan dalam bidang pertambangan, sebab IUPK diberikan oleh Menteri tidak memperhatikan kepentingan daerah atau Pemegang IUPK tidak menggunakan haknya untuk membuat suatu pernyataan bahwa dia tidak berminat untuk mengusahakan mineral lain selain mineral yang telah diizinkan baginya untuk diusahakan namun secara kebetulan dia menemukannya menurut izin yang pertama diberikan.

Kategori kejahatan atau perbuatan tidak adil dalam bidang pertambangan yang kedua, yaitu tindak pidana misrepresentation dan fraud, dan diancam dengan sanksi pidana sebagaimana diatur dalam Pasal 159 UU Minerba. Dirumuskan dalam Pasal tersebut, yang menegaskan bahwa pemegang IUP, IPH, atau IUPK yang dengan sengaja menyampaikan laporan sebagaimana dimaksud dalam Pasal 43 ayat (1), Pasal 70 huruf e, Pasal 81 ayat (1), Pasal 105 ayat (4), Pasal 110, atau Pasal 111 ayat (1) dengan tidak benar atau menyampaikan keterangan palsu di pidana dengan pidana penjara paling lama 10 (sepuluh) tahun dan denda paling banyak Rp 10.000.000.000,00 (sepuluh miliar rupiah).

Berikut beberapa bentuk kejahatan atau ketidakadilan dalam bidang pertambangan sebagaimana diatur secara berturut-turut, dalam Pasal 43 ayat (1), Pasal 70 huruf e, Pasal 81 ayat (1), Pasal 105 ayat (4), Pasal 110, atau Pasal 111 ayat (1) tersebut. Kejahatan yang diatur dalam Pasal 43 ayat (1) berhubungan dengan kewajiban menyampaikan laporan tentang pelaksanaan dari izin yang telah diterima baik itu oleh pemegang IUP, IPR atau IUPK. Dirumuskan dalam Pasal 43 ayat (1) menegaskan bahwa dalam hal kegiatan eksplorasi dan kegiatan studi kelayakan, pemegang IUP Eksplorasi yang mendapatkan mineral atau batubara yang tergali wajib melaporkan kepada pemberi IUP.

Apabila laporan pihak pemegang IUP Eksplorasi yang disampaikan kepada pemberi IUP tersebut secara tidak benar atau misrepresentation maka hal itu merupakan bentuk kejahatan yang diancam denan sanksi pidana menurut UU Minerba. Begitu pula apabila laporan yang disampaikan oleh pihak pemegang IUP eksplorasi tersebut berisi keterangan yang dipalsukan atau fraud, maka pihak pemegang IUP Eksplorasi itu juga dapat dijatuhi sanksi pidana penjara dan denda sebagaimana telah dikemukakan dalam rumusan Pasal 159 UU Minerba di atas. 
Ancaman sanksi pidana juga dapat dijatuhi kepada pihak pemegang IPR. Dalam Pasal 70 hurif (e) UU Minerba dirumuskan bahwa: pihak pemegang IPR wajib menyampaikan laporan pelaksanaan kegiatan usaha pertambangan rakyat secara berkala kepada pemberi IPR. Apabila pihak pemegang IPR tersebut menyampaikan laporan pelaksanaan kegiatan usaha pertambangan rakyat secara berkala kepada pemberi IPR, namun laporan tersebut mengandung ketidakbenaran maupun merupakan laporan palsu, maka ancaman yang sama, yang diatur dalam Pasal 159 di atas juga dapat dikenakan kepadanya.

Dikatakan sebagai kejahatan atau bentuk ketidakadilan lainnya yang diancam dengan pidana sebagaimana diatur dalam Pasal 159, yaitu apabila laporan yang disampaikan oleh pihak pemegang IUPK eksplorasi yang mendapatkan mineral logam atau batu bara yang tergali, namun pihak tersebut melaporkan secara tidak benar dan mengandung isi yang dipalsukan. Hal itu diatur dalam Pasal 81 ayat (1) UU Minerba. Begitu pula dengan pengaturan mengenai kewajiban badan usaha yang tidak bergerak pada usaha pertambangan yang bermaksud menjual mineral dan/atau batubara yang tergali. Apabila badan usaha itu tidak menyampaikan laporan hasil penjualan mineral dan/atau batubara yang tergali kepada Menteri, Gubernur, atau Bupati/Walikota sesuai kewenangannya, juga dikenakan sanksi yang diatur dalam Pasal 159 UU Minerba.

Pasal 110 UU Minerba mengatur tentang kewajiban pemegang IUP dan IUPK menyerahkan seluruh data yang diperoleh dari hasil eksplorasi dan operasi produksi kepada Menteri, Gubernur, atau Bupati/Walikota sesuai dengan kewenangannya. Apabila seluruh data yang diperoleh dari hasil eksplorasi dan operasi produksi yang disampaikan kepada pihak yang berwenang itu tidak benar dan palsu, maka hal itu merupakan suatu bentuk kejahatan pula, yang diancam dengan pidana sebagaimana diatur dalam Pasal 159 UU Minerba.

Dalam Pasal 111 ayat (1) 159 UU Minerba ditentukan bahwa pihak pemegang IUP dan IUPK wajib memberikan laporan tertulis secara berlaka atas rencana kerja dan pelaksanaan kegiatan usaha pertambangan mineral dan batubara kepada Menteri, Gubernur, atau Bupati/Walikota sesuai dengan kewenangannya. Apabila laporan tertulis secara berkala atas rencana kerja dan pelaksanaan kegiatan usaha pertambangan mineral dan batubara kepada
Menteri, Gubernur, atau Bupati/Walikota itu berisi keterangan yang tidak benar atau dipalsukan, maka kepada pihak tersebut dapat dikenakan pidana yang diancam pada Pasal 159 UU Minerba.

Secara singkat dapat dikatakan bahwa apabila pihak pemegang IUP, IPR dan IUPK menyampaikan laporan, keterangan atau data mengenai ditemukannya mineral atau batubara yang tergali, pengelolaan lingkungan hidup, penjualan mineral atau batubara, rencana kerja, dan pelaksanaan kegiatan usaha pertambangan secara misrepresentasi atau palsu, maka yang bersangkutan adalah pelaku kejahatan pertambangan yang diancam dengan pidana yang telah ditentukan dalam Pasal 159 UU Minerba. Perlu dikemukan pula ketentuan yang berkaitan dengan pemberian laporan sebagaiman dimaksudkan di atas harus dilakukan oleh pihak-pihak pemegang IUP, IPR, dan IUPK setiap empat bulan.

Kategori kejahatan atau ketidakadilan yang ketiga, yaitu perbuatan pidana berupa melakukan kegiatan eksplorasi tanpa memiliki IUP atau IUPK. Berkaitan dengan itu, adalah merupakan kejahatan pula apabila ada pihak yang mempunyai IUP eksplorasi tetapi melakukan kegiatan operasi produksi, maka sesuai dengan apa yang diatur dalam Pasal 160 UU Minerba pihak-pihak dimaksud dapat dijatuhi pidana kurungan paling lama satu tahun atau denda paling banyak dua ratus ribu rupiah. Sanksi yang dijatuhkan kepada pelaku dalam kategori tindak pidana pertambangan yang ketiga sebagaimana dikemukakan di atas bersifat alternatif. Artinya, penjahat pertambangan dapat dijatuhi sanksi pidana kurungan saja atau denda saja. Sifat alternatif itu disebabkan oleh rumusan sanksi dalam rumusan Pasal 160 yang menggunakan kata atau.

Sehubungan dengan persoalan di sekitar batas antara kejahatan dan pelanggaran yang sudah dikemukakan di atas, maka berkenaan dengan Pasal 160 UU Minerba ini dapat dikemukakan suatu pandangan bahwa undang-undang ini juga menarik garis batas antara kejahatan atau misdrijf dan pelanggaran atau overtreding. Pandangan seperti itu didasarkan kepada argumentasi yuridis, bahwa pembagian hukuman seperti yang diadakan dalam KUHP itu adalah sebagai berikut.

Hukuman yang dijatuhkan dalam hal kejahatan pada umumnya lebih berat daripada hukuman yang dijatuhkan dalam hal pelanggaran. Kalau kejahatan dihukum dengan dijatuhi hukuman kurungan dan 
hukuman denda, artinya bersifat kumulatif. Kurungan atau Penjara plus denda. Sedangkan hukuman yang dijatuhkan kepada pelanggaran adalah hukuman kurungan atau hukuman denda, yaitu bersifat alternatif, sebagaimana dirumuskan dalam Pasal 160 UU Minerba yang telah dikemukakan di atas.

Kategori kejahatan pertambangan selanjutnya, yang dikenal dalam UU Minerba, yaitu penggunaan jenis izin pertambangan yang tidak sesuai dengan peruntukkannya. Dirumuskan dalam Pasal 161 UU Minerba, bahwa Setiap orang atau pemegang IUP Operasi Produksi atau PUPK Operasi Produksi yang menampung, memanfaatkan, melakukan pengolahan dan pemurnian, pengangkutan, penjualan mineral dan batubara yang bukan dari pemegang IUP, IUPK, atau izin sebagaimana dimaksud dalam Pasal 37, Pasal 40 ayat (3), Pasal 43 ayat (2), Pasal 48, Pasal 67 aya t (1), Pasal 74 ayat (I), Pasal 81 ayat (2), Pasal 103 ayat (2), Pasal 104 ayat (3), atau Pasal 105 ayat (1) dipidana dengan pidana penjara paling lama 10 (sepuluh) tahun dan denda paling banyak Rp 10.000.000.000,00 (sepuluh miliar rupiah).

Hal itu dapat diartikan bahwa pemegang IUP hanya diberikan hak dalam perizinan yang diberikan kepadanya untuk melakukan suatu kegiatan dalam pentahapan tertentu saja. Namun apabila kegiatan itu sudah selesai dilakukan maka pihak tersebut wajib untuk mengajukan IUP berikutnya. Seorang yang telah diberikan IUP eksplorasi, tidak boleh melakukan kegitan operasi produksi sebelum memperoleh IUP operasi produksi.

Dalam Pasal 161 UU Minerba dirumuskan bahwa sanksi yang dapat dijatuhkan kepada pihak yang melakukan kegiatan operasi produksi padahal baru memperoleh IUP untuk eksplorasi pada hakikatnya melakukan tindak pidana. Sanksi yang dijatuhkan dapat berupa pidana penjara paling lama lima tahun dan denda paling banyak sepuluh miliar rupiah.

Kategori dalam kejahatan pertambangan atau ketidakadilan yang harus dihindari dalam kegiatan pertambangan, yang selanjutnya menurut UU Minerba, yaitu menampung, memanfaatkan, melakukan pengelolaan dan pemurnian, pengangkutan, penjualan mineral dan batubara yang bukan dari pemegang IUP, IUPK, atau pemegang izin sebagaimana dimaksud dalam Pasal 37, Pasal 43 ayat (3), Pasal 43 ayat (2), Pasal 48, Pasal 67 ayat (1), Pasal 74 ayat (1), Pasal 81 ayat (2), Pasal 103 ayat (2), Pasal 104 ayat (3), atau Pasal 105 ayat (1) UU Minerba.
Telah dikemukakan di atas, bahwa Pasal 37 UU Minerba mengatur mengenai siapa sajakah pejabat yang memiliki wewenang untuk menerbitkan perizinan dalam bidang pertambangan. Manakala ada pihak yang melakukan kegiatan penampungan, memanfaatkan, melakukan pengolahan dan pemurnian, pengangkutan, penjualan mineral atau batubara yang bukan dari pemegang IUP, IUPK, atau pemegang izin maka yang bersangkutan dapat dikatakan melakukan kejahatan pertambangan dan kepadanya dapat dijatuhi pidana sebgaimana telah ditentukan dalam Pasal 161 UU Minerba di atas.

Sementara itu, Pasal 40 ayat (3) UU Minerba mengatur bahwa pemegang IUP yang bermaksud mengusahakan mineral lain wajib mengajukan permohonan IUP baru kepada Menteri, Gubernur, dan Bupati/Walikota sesuai dengan kewenangannya. Artinya, apabila ada pihak yang melakukan kegiatan penampungan, memanfaatkan, melakukan pengolahan dan pemurnian, pengangkutan, penjualan mineral atau batubara yang bukan dari pemegang IUP, IUPK, atau pemegang izin yang belum diperoleh tersebut maka yang bersangkutan dapat dikatakan melakukan kejahatan pertambangan dan kepadanya dapat dijatuhi pidana sebgaimana telah ditentukan dalam Pasal Pasal 161 UU Minerba di atas.

Begitu pula dengan ketentuan dalam Pasal 43 ayat (2), bahwa pemegang IUP yang menemukan mineral lain di dalam WIUP yang dikelola diberikan prioritas untuk mengusahakannya. Hanya saja, yang bersangkutan wajib untuk mengajukan permohonan izin baru.

Apabila ada pihak yang melakukan kegiatan penampungan, memanfaatkan, melakukan pengolahan dan pemurnian, pengangkutan, penjualan mineral atau batubara yang bukan dari pemegang IUP, IUPK, atau pemegang izin yang belum diperoleh tersebut maka yang bersangkutan dapat dikatakan melakukan kejahatan pertambangan dan kepadanya dapat dijatuhi pidana sebgaimana telah ditentukan dalam Pasal 161 UU Minerba di atas.

Kategori kejahatan pertambangan selanjutnya, yaitu kejahatan berupa merintangi atau menggantu kegiatan usaha pertambangan. Hal itu diatur dalam Pasal 162 UU Minerba. Dirumuskan di sana, bahwa setiap orang yang merintangi atau mengganggu kegjatan usaha pertambangan dari pemegang IUP atau IUPIC yang telah memenuhi syarat-syarat sebagaimana dimaksud dalam Pasal 136 ayat (2) di 
pidana dengan pidana kurungan paling lama 1 (satu) tahun atau denda paling banyak $\mathrm{Rp} 100.000 .000,00$ (seratus juta rupiah). Dalam Pasal 136 ayat (2) dapat diketahui bahwa kejahatan itu ditujukan kepada pihak-pihak yang menguasai hak-hak atas tanah menurut peraturan perundangan yang berlaku, agar melakukan penyelesaian hak atas tanah dengan pihak-pihak pemegang IUP dan IUPK sesuai dengan peraturan perundang-undangan yang berlaku.

Apabila penyelesaian itu sudah dicapai maka hendaknya pihak-pihak itu tidak lagi menghalangi pemegang IUP dan IUPK untuk melakukan kegiatan usaha pertambangan sesuai dengan perizinan yang telah diperolehnya. Suatu hal yang penting untuk dikemukakan disini, bahwa apabila mengikuti kategori pembagian kejahatan dan pelanggaran sebagaimana telah dikemukakan di atas, maka rumusan pidana maupun ancaman sanksi pidana yang terdapat dalam Pasal 162 UU Minerba tersebut merupakan tindak pidana pelanggaran.

Kategori kejahatan pertambangan yang terakhir, yaitu penyalahgunaan kewenangan atau abuse of power dari pihak yang mempunyai wewenang untuk mengeluarkan IUP, IPR, atau IUPK. Dirumuskan dalam Pasal 165 UU Minerba bahwa setiap orang yang mengeluarkan IUP, IPR, atau IUPK yang bertentangan dengan UU Minerba dan menyalahgunakan kewenangannya diberi sanksi pidana paling lama dua tahun penjara dan denda paling banyak dua ratus juta rupiah.

\section{PENUTUP}

\section{Kesimpulan}

Hukum hadir dalam mengatasi kejahatan, pelanggaran atau ketidakadilan dalam kegiatan pertambangan. Kehadiran hukum itu dalam perspektif Teori Keadilan Bermartabat dapat dilihat manifestasi atau pengejawantahannya dalam peraturan perundangundangan yang mengatur mengenai pertambangan. Satu di antara regulasi tentang pertambangan itu, yaitu UU Minerba adalah salah satu wujud konkret dari kehendak atau jiwa bangsa (Volksgeist) dalam bidang pertambangan. Di dalam undang-undang itu, telah ditentukan jenis kejahatan atau bentuk ketidakadilan apa saja yang dapat terjadi dalam bidang pertambangan.

Berbagai jenis sanksi juga disiapkan sebagai sarana hukum untuk mengatasi kejahatan, pelanggaran atau bentuk-bentuk ketidakadilan, baik yang dilakukan oleh individu, mapun yang dilakukan oleh badan hukum, serta pihak ketiga yang terkait dalam bidang pertambangan tersebut. Tujuan dari UU Minerba yaitu memastikan bahwa kegiatan usaha pertambangan mineral dan batubara yang merupakan kegiatan usaha pertambangan di luar panas bumi, minyak dan gas bumi serta air tanah mempunyai peranan penting dalam memberikan nilai tambah secara nyata kepada pertumbuhan ekonomi nasional dan pembangunan daerah secara berkelanjutan.

\section{Rekomendasi}

Dalam perspektif Teori Keadilan Bermartabat, maka UU Minerba sesuai dengan jiwa bangsa. Dalam hukum, aktivitas tidak hanya pada proses pembuatan hukum, tetapi proses pelaksanaan justru lebih penting. Oleh karena itu penegakan hukum perlu diperhatikan agar tujuan adanya UU Minerba bisa direalisasikan.

\section{DAFTAR PUSTAKA}

\section{Peraturan Perundang-undangan:}

Undang-Undang Dasar Negara Republik Indonesia Tahun 1945.

Undang-Undang Republik Indonesia Nomor 4 Tahun 2009 tentang Pertambangan Mineral dan Batubara.

\section{Buku:}

E., Utrecht dan Moh. Saleh Djindang, 1983, Pengantar dalam Hukum Indonesia, Cetakan Kesepuluh, Jakarta: Ichtiar Baru dan Sinar Harapan.

Mertokusumo, Sudikno, 1999, Mengenal Hukum Suatu Pengantar, Cetakan Kedua, Yogyakarta: Liberty.

Prasetyo, Teguh dan Abdul Halim Barkatullah, 2012, Filsafat, Teori, \& Ilmu Hukum Pemikiran Menuju Masyarakat yang Berkeadilan dan Bermartabat, Cetakan ke-1, Jakarta: RajaGrafindo Persada.

Prasetyo, Teguh, 2013, Hukum Pidana, Edisi Revisi, Cetakan Keempat, Jakarta: RajaGrafindo Persada.

, 2013, Hukum dan Sistem Hukum Berdasarkan Pancasila, Cetakan Pertama, Yogyakarta: Media Perkasa.

, 2015, Keadilan Bermartabat Perspektif

Teori Hukum, Cetakan Pertama, Bandung: Nusa Media.

Wignjosoebroto, Soetandyo, 2013, Pergeseran Paradigma dalam Kajian-kajian Sosial dan 
Hukum, Edisi Revisi, Cetakan Pertama, Malang: Wilk, Kurt, 1950, 20 $0^{\text {th }}$ Century Legal Philosophy Setara Press. Series, Vol., IV, The Legal Philosophies of Lask, Radbruch, and Dabin, Harvard University Press. 